and the imminence of doomsday. Nartsissov's poetry, radiating an enlightened, spiritual attitude toward the world, is original and innovative.

Boris Nartsissov will be warmly remembered by his friends and the admirers of his poems.

Temira Pachmuss

University of Illinois at Urbana-Champaign

\title{
MICHAEL GINSBURG, 1902-1982
}

Michael Ginsburg, professor emeritus of Slavic languages and literatures and the first chairman of the Indiana University Slavic department, died on October 18, 1982 in New York City, where he and Mrs. Ginsburg, the former Edith Davis, had resided since his retirement in 1966.

Ginsburg was born on September 1, 1902 in Moscow, the son of the distinguished Jewish scholar and cultural leader Saul Ginsburg. He received his early education in St. Petersburg at the St. Catherine School and the Classical High School and earned degrees in jurisprudence from Demidov Law College in Iaroslavl' in 1920 and from Petrograd University in 1925. Emigrating to France shortly thereafter, he earned the doctorat ès lettres in 1931 at the University of Paris. Later that year he came to the United States and joined the faculty of the University of Nebraska as assistant professor of East European history and classical philology and archaeology. He was promoted to associate professor in 1938 and to professor in 1940. During World War II, while on leave from his university post, he served as an intelligence officer in the United States Air Force, and from 1945 to 1947 he was chief of the Internal Political Section in the USSR Division of the Office of Research and Intelligence at the Department of State.

Russian had been taught at Indiana University on a special basis during World War II, but it was only with Ginsburg's appointment to the Indiana University faculty in 1947 that Russian became a part of the university's regular program of study. Thanks to his vigorous pioneering work, within two years after his appointment the university established a Department of Slavic Studies and named Ginsburg as its first chairman, and in 1950 the Graduate School approved a program leading to an M.A. in Slavic Studies. In the summer of 1951 Ginsburg organized the first annual summer Russian Workshop, and in 1956 he took the first steps that were to lead at the end of 1958 to the establishment of a $\mathrm{Ph} . \mathrm{D}$. program in Slavic languages and literatures.

Throughout his teaching career at Indiana, Ginsburg's scholarly interest was focused on the whole of Russian culture. He was naturally interested in Russian literature, but he saw literature as only one branch of a living organism that includes the theater, architecture, painting, sculpture, and music as well. He constantly emphasized that none of these fruits of Russian culture could be properly understood apart from the political, economic, religious, and social conditions in which they had developed. Three intertwined themes are notable in his scholarly writing: jurisprudence, classical philology, and Jewish culture, particularly in its relation to Russian culture. He was awarded two Guggenheim Fellowships, one in 1939 and the other in 1942.

Michael Ginsburg was one of Indiana University's last living links with the rich Russian culture of the period immediately preceding the Revolution of 1917 . He belonged to the generation of Russian émigré scholars and intellectuals who played a pioneering role in establishing Russian studies in the United States. Indiana University's Department of Slavic Languages and Literatures and its interdepartmental Russian and 
East European Institute have both grown directly out of the work that began in 1947 with his appointment to the Indiana faculty.

William B. Edgerton

Indiana University 